\title{
A serdülőkori lábszártörés kezelése felfúrás nélküli, tömör, reteszelt velőứrszegezéssel*
}

\author{
DR. KRETZER ANDRÁS, DR. TÖMBÖL FERENC, DR. BURKUS MÁTÉ
}

\section{ÖSSZEFOGLALÁS}

A gyermekkori lábszártörések kezelése elsősorban konzervativan végzendő, de a mútéti ellátás aránya az elmúlt időszakban egyértelmű emelkedést mutat. Az operatív beavatkozások során elsősorban elasztikus intramedullaris rögzítési módszer használatos, míg a felnőtteknél alkalmazott tömör, reteszelt velőurrszegezés, a nyitott epiphysis fuga jelenléte miatt nem javasolt. 2007 és 2017 között osztályunkon 14 esetben végeztünk nyitott epiphysis fugával rendelkező serdülőkorú (átlagéletkor 13,7 év) lábszár diaphysis töröttnél felfúrás nélküli, tömör, reteszelt velőűrszegezést, egyedi, az epiphysist elkerülő mútéti technikával. Az alkalmazott eljárás minden esetben jó funkcionális gyógyulást eredményezett. A teljes terhelés engedélyezésének ideje átlagosan $7,8 \pm 2,5$ hét volt, míg a törésgyógyulás átlagos ideje 11,3 $\pm 2,8$ hétnek mutatkozott. Három esetnél minor, sebbel kapcsolatos szövődményt tapasztaltunk, míg mély infekció, compartment syndroma, valamint későbbi végtaghossz eltérés nem igazolódott. A jelen közleményben bemutatott módosított technikával végzett velőűrszegezés jó eredménnyel alkalmazható alternativ eljárás lehet, a serdülőkori lábszár test törések operatív kezelésében. A módszer használatával alacsony szövődményráta mellett gyors és jó funkcionális gyógyulás érhető el.

\section{Kulcsszavak: $\quad$ Epiphysis; Lábszártörés; Nyílt törés; Serdülökor; Tibia törés; Velöürszegezés;}

A. Kretzer, F. Tömböl, M. Burkus: Adolescents tibial fracture treated with undreamed, solid, locked intramedullary nailing

Tibial fractures in children mainly treated with conservative methods, although the incidence of surgical interventions are exceeding. During operations mostly flexible intramedullary nailing is used. Solid, undreamed, nailing technique, frequently used in adults, is not recommended because of the open physis. Between 2007 and 2017 in our institute solid undreamed, locked intramedullary nailing were used in 14 adolescent cases (average age 13,7 years) with open physis. During all operations unique physis avoiding technique were performed. In all cases good primer healing were achieved. The mean time of full weight bearing permission were $7,8 \pm 2,5$ weeks, while the average healing time were $11,3 \pm 2,8$ weeks. In 3 cases minor, wound related complications were observed, deep infection, compartment syndrome, or late leg length discrepancy were not noticed. The nailing technique used in the current study could be a safe, alternative fixing method in case of adolescents tibial fractures. It provides good functional and quick healing with low complication rate.

Keywords: $\quad$ Adolescent; Epiphyses - Injuries/Surgery; Fracture fixation, intramedullary - Methods;

Fractures, open - Surgery; Tibial fractures - Surgery;

\footnotetext{
*Ezen cikket tanítómesterünk, Dr. Dékány Sándor Főorvos Úr emlékére ajánljuk: PAMOK Balesetsebészeti és Kézsebészeti Osztálya
} 


\section{BEVEZETÉS}

A gyermekkorban előforduló lábszártörés a combcsont- és alkartörések melletti egyik leggyakoribb töréstípus, amelynek megjelenése egyértelmú fiú túlsúlyt mutat $(5,6,8)$. A törések tisztán diaphysisre való lokalizációja az esetek akár $40 \%$-át is kiteheti, illetve közel 10\%-ban járulékos nyíltság is fennállhat (15).

A tibiatörések kezelése az elmúlt évtizedekben jelentős változáson ment keresztül. A gyermekek esetén korábban alkalmazott, közel teljesen konzervatív szemlélet mellé egy egyre hangsúlyosabb operatív vonal jelent meg, mindazonáltal a gyermekkor jelentette speciális adottságok - jó gyógyhajlam - miatt a konzervatív módszerek, az esetek többségében jelenleg is jó eredményekkel és alacsony szövődményrátával alkalmazhatók $(1,9,16)$. Gordon és munkatársai közleményükben részletesen foglalkoznak a tibiatörés mútéti indikációival, miszerint a megfelelő törésállás esetén közel minden eset kezelhető konzervatívan. Nem kielégítő törésállás, járulékos nyíltság, illetve jelentős duzzanattal járó eseteknél viszont inkább a mútét javasolt, ugyanúgy, mint ipsilateralis femurtörés, illetve lengő térd fennállásakor is (8).

A gyermekeknél végzett mútéti ellátás a nyitott epiphysis fuga jelenléte miatt, a felnőtteknél alkalmazottól eltérő módon végzendő. A mútétek során előszeretettel használt, relatíve könnyú és effektív módszer az elasztikus intramedullaris szegezés. A technika jó eredményekkel való alkalmazhatóságát, reprodukálhatóságát, valamint alacsony szövődményrátáját, instabil vagy akár nyílt törések mellett is, számos közlemény taglalja (5-9, $11,14,16,18,19)$. Srivastava és munkatársai szerint azonban a módszer fokozottabb odafigyelést igényel lábszártörés esetén, mint a combcsontnál, a rotáció és balansz pontosabb helyreállítási igénye miatt (18). A mútéti ellátás során az elasztikus rögzítési módszereken túl jó eredményekkel alkalmazhatók a különböző fixateur externe technikák is, mind a primer ellátás során, mind pedig szövődményes esetek kezelésében $(2,8,14)$. Kubiak és munkatársai 16 elasztikus szegezéssel és 15 külső rögzítéssel kezelt esetnél végzett összehasonlító vizsgálata során közel azonos eredményeket tapasztaltak, de eredményeikben a szegezéssel operáltak törése némiképp hamarabb konszolidálódott, míg a fixateur esetén emelkedettebb szövődményráta mutatkozott (10). A felnőtteknél gyakran használt lemezes osteosynthesisek gyermekkorban való alkalmazhatósága limitált. Ennek oka részben a kiterjedt feltárás igénye, így a következményes lágyrészkárosodás, továbbá egyes vizsgálatok szerint a 12 éves kor alatt végzett lemezelés a kiváltott stimuláló hatás révén növekedést képes indukálni, amely aszimmetrikus végtaghosszt eredményezhet (13).

A konzervatív kezeléssel szerzett jó tapasztalatok, a rendelkezésre álló mútéti lehetőségek, valamint a gyermekeknél fennálló, a felnőttekéhez viszonyítottan kifejezetten jobb gyógyhajlam ellenére, a tibia diaphysis törések kezelése összetett és nehéz feladat. Ez különösképp igaz a serdülőkorban lévő gyermekekre ahol a testméretek már gyakran felnőttkori léptékúek, mindazonáltal a növekedési zónák aktivitása még fennáll. A fokozott fizikum és a teljes funkció mielőbbi visszanyerésének igénye miatt (például versenysportolók) a standard velőurszegezés jó mútéti alternatíva lehet, ahogy ezt már több közlemény szerzője is felvetette. Setter és munkatársai közleményükben említést tesznek tömör szeg alkalmazhatóságáról, de annak használatát - a szokásos behatolás potenciális epiphysis fugát károsító hatása miatt - nem javasolják (16). Az irodalom áttekintése során a szerzők csupán egy olyan közleményt találtak, amely ténylegesen velőúrszegezési módszert alkalmaz a növekedés lezárulta előtt. Court-Brown és munkatársai 36 esetnél használtak üreges felfúrásos reteszelt velőurrszegezést, némiképp módosított, de a physist érintő behatolás mellett (4).

Jelen vizsgálat célja volt, hogy a szerzők saját tapasztalataikat mutassák be, az intézetükben alkalmazott atípusos módon, teljes physis kímélet mellett végzett, gyermekkori lábszártörés ellátására használt, felfúrás nélküli, tömör, reteszelt velőűrszegezéssel kapcsolatban.

\section{ANYAG ÉS MÓDSZER}

Regionális balesetsebészeti és kézsebészeti centrumként múködő osztályunk elsődleges profilja a felnőtt ellátás, míg kisebb részben gyermek traumatológiai ambuláns és operatív 
kezelést is végez. A gyermek sérültek akut ambuláns ellátása jelenleg még közös felnőtt-gyermek sürgősségi osztály balesetsebészeti részlegén történik, de a gyermeksérült hospitalizációjára különálló gyermeksebészeti, gyermekgyógyászati - illetve gyermek intenzív - osztályon van lehetőség.

A 2007 és 2017 közötti időszakban az akut traumatológiai ambulancián évente, átlagosan közel 32500 megjelenés történt, amelyek közül átlag 6700 esetben volt 18 év alatti az ellátott, amely 20,5\%-os arányt jelentett. Ezen időszak során az összes lábszártöréssel járó esemény mintegy 2645 esetet tett ki, amelyből 487 $(18,4 \%)$ volt gyermekkorú. Kezelésük során 396 esetben $(81,3 \%)$ konzervatív terápiát alkalmaztunk, míg 91 estben $(18,7 \%)$ mútéti beavatkozás történt.

Jelen közlemény azon lábszártest törést szenvedett eseteket foglalja össze, ahol a még nyitott epiphysis fuga jelenléte mellett történt tömör velőűrszeg behelyezés, epiphysis kímélő módszerrel.

Vizsgálatunkba összesen 14 esetet tudtunk bevonni; átlagéletkora: 13,7 $\pm 1,25$ év (szórás 12-16 év). Az esetek nemi megoszlását az I. táblázatban tüntettük fel. Vizsgálatunkban a velőurrszegezés aránya az összes gyermekkori lábszártörés mútéthez viszonyítva $15,4 \%$ volt. A mútéti indikáció a fokozott testméret, elsősorban testtömeg, átlag: 60,6 \pm 13,5 kg (megoszlás 48-102 kg) volt.

A sérülések keletkezésének körülményeit tekintve azok 5 esetnél téli sport közben, 3 sérültnél futball közben, míg további 3 esetnél otthoni balesetben alakultak ki. Egy esetnél a törés egy pár héttel korábban operált csontcystát érintve következett be, így azt patológiásnak tekintettük. Továbbá 2 gyermek motorkerékpárral - mindegyikük motocross versenyen - sérült. 13 esetben zárt törés, míg 1 esetben első fokban nyílt törés állt fenn. A részletes $A O$ szerinti klasszifikáción alapuló megoszlásukat a II. táblázatban tüntettük fel.

A mútéti ellátás 8 esetnél a sérülés keletkezést követően 24 órán belül megtörtént, míg 1 esetnél szociális okok miatt, további 5-nél pedig a (részben saját, részben más intézetben kezdett) konzervatív kezelés kontrollján észlelt diszlokáció miatt halasztva (4-14. nap között) végeztük el.

A mútéti ellátás során minden esetben az intézetünkben a felnőtt traumatológia ellátás során rutinszerűen alkalmazott, és rendelkezésre álló standard, tömör felfúrás nélküli reteszelt tibia velőurrszeget és implantátum behelyező rendszert (Medimetal kft., Eger, Magyarország) használtuk (1. ábra).

A beavatkozások során a hagyományos (felnőttkori) lábszár velőúrszegezésnél alkalmazott transligamentalis behatolás helyett, az epiphysis teljes elkerülésére törekedve a szeg bevezetése atípusos módon történt. A bőrmetszést a tuberositas tibiae-től 2-3 cm-re distalra és kissé medialra ejtettük, és itt készült az implantátum bevezetésére szolgáló csontablak is (2. ábra), különösen odafigyelve a proximalra történő elcsúszás elkerülésére, a physis épségének megtartására. A beavatkozások során a csont tömörsége - vastag corticalis, szűk velőűr - miatt az elérhető legvékonyabb, 8 mm-es szeget alkalmaztuk. A repozíciót, a szeg bevezetését és a reteszelést képerősítő kontroll alatt végeztük, amely során szintén kiemelt figyelmet fordítottunk arra, hogy mind a proximalis, mind a distalis epiphysis fuga érintetlen maradjon.

I. táblázat Az esetek életkor és nem szerinti megoszlása

\begin{tabular}{|c|c|c|c|c|c|c|c|}
\hline Életkor (év) & 11 & 12 & 13 & 14 & 15 & 16 & Összes \\
\hline Fiú & 1 & 0 & 3 & 3 & 3 & 1 & 11 \\
\hline Lány & 0 & 1 & 1 & 1 & 0 & 0 & 3 \\
\hline
\end{tabular}




\begin{tabular}{|c|c|c|c|c|c|c|c|c|c|c|c|c|c|c|c|}
\hline II. táblázat A tibiatörése felosztása lokalizáció, illetve AO klasszifikáció alapján \\
\hline $\begin{array}{c}\text { Eset } \\
\mathbf{1}\end{array}$ & $\mathbf{2}$ & $\mathbf{3}$ & $\mathbf{4}$ & $\mathbf{5}$ & $\mathbf{6}$ & $\mathbf{7}$ & $\mathbf{8}$ & $\mathbf{9}$ & $\mathbf{1 0}$ & $\mathbf{1 1}$ & $\mathbf{1 2}$ & $\mathbf{1 3}$ & $\mathbf{1 4}$ \\
\hline $\begin{array}{c}\text { Törés lokalizáció } \\
\text { (heted) }\end{array}$ & 4 & 5 & 4 & 4 & 4 & 6 & 4 & 5 & 5 & 4 & 4 & 5 & 4 & 6 \\
\hline $\begin{array}{c}\text { AO beosztás } \\
\text { (42/) }\end{array}$ & B1 & B1 & C1 & B2 & B1 & B1 & B1 & B1 & B1 & B2 & B1 & B1 & A2 & A3 \\
\hline
\end{tabular}
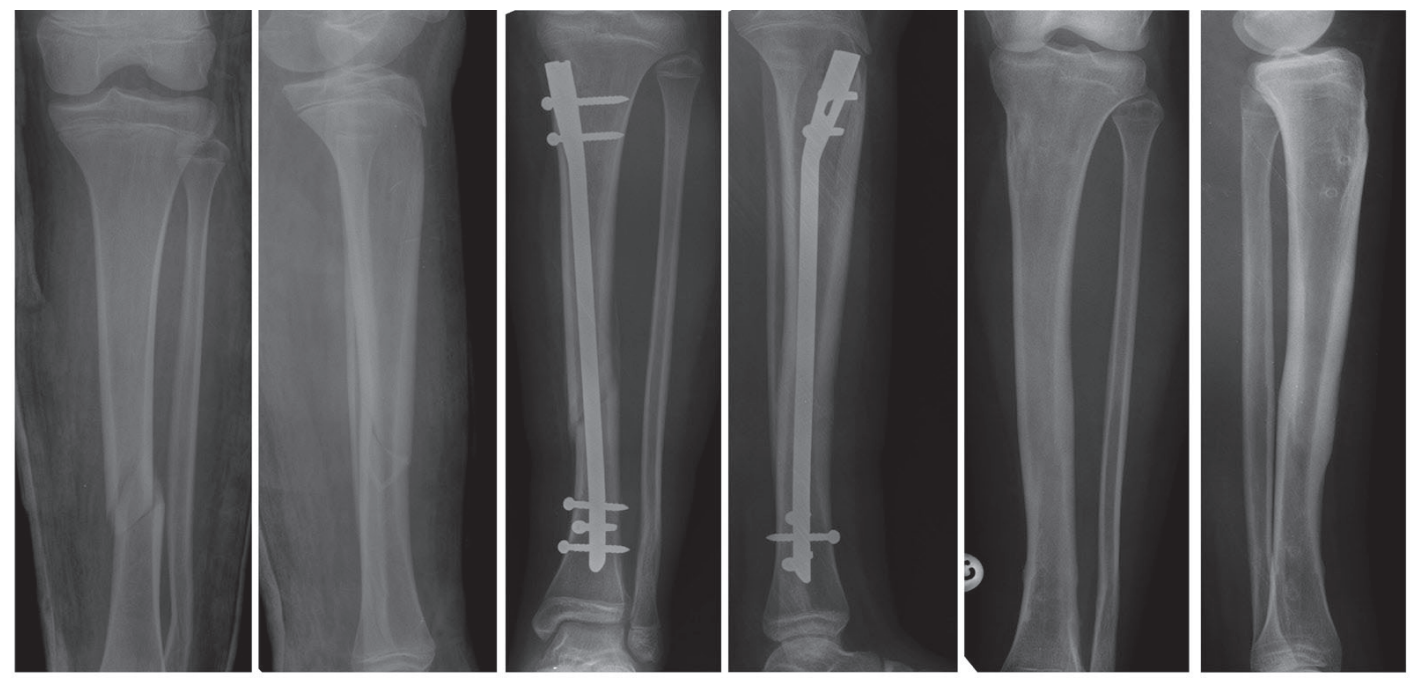

1. ábra 13 éves lánygyermek lábszártörésének kezelése konzervativ módszerrel indult, majd a kontrollvizsgálaton észlelt dislocatio és tengelyeltérés miatt mütéti beavatkozás történt. Az alkalmazott eljárással jó funkcionális gyógyulás volt elérhetö.

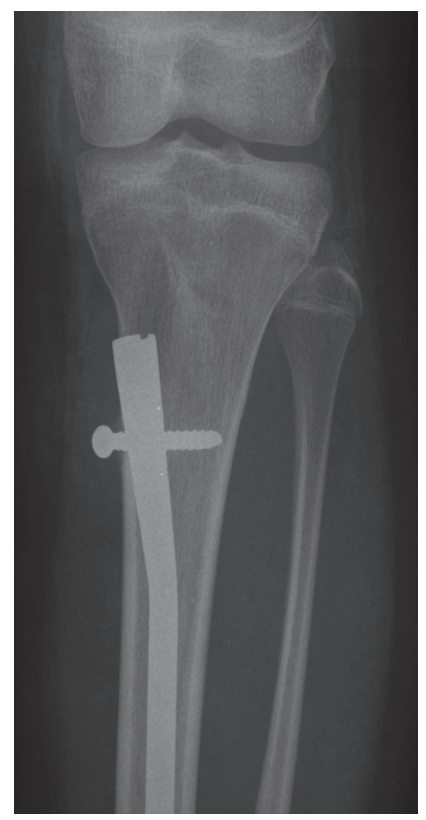

2. ábra Az implantátumok bevezetése a tuberositas tibiae-töl kissé medialra és distalra történt. 


\section{EREDMÉNYEK}

A bemutatott atípusos velőurrszegezési módszerrel minden esetnél teljes, primer gyógyulást értünk el. Elhúzódó törésgyógyulás, álízület kialakulás, implantátum kimozdulás nem igazolódott, így módszerváltásra, reoperációra sem volt szükség. A beavatkozásokat követően kiegészítő gipszrögzítés alkalmazása nem történt. Az átlagos kórházi ápolási napok száma 6,4 \pm 2,1 nap volt. Az eseteket a posztoperatív 12. hétig kéthetente, majd továbbiakban a 20. hétig 4 hetente kontrolláltuk.

A posztoperatív terhelés megkezdése 5 esetnél már közvetlen a mútét után lábsúlylyal megtörtént, míg a többi esetnél a 3-4. posztoperatív héten volt megkezdhető. A teljes terhelés átlagosan 7,8 $\pm 2,5(4-12)$ hetesen került engedélyezésre. A radiológiai törésgyógyulás átlagosan $11,3 \pm 2,8(8-16)$ hét alatt alakult ki. A sérülteknek a fokozott fizikális terheléshez, sporthoz való visszatérését átlagosan $20 \pm 3,5$ hetesen engedélyeztük.

A mütétek során összesen 3 esetnél tapasztaltunk intraoperatívan az atípusos szegbehelyezés körül kialakult kisebb, iatrogen csont corticalis sérülést, amely további ellátást egy esetben sem igényelt (3. ábra). Két esetnél kezdődő lokális infekciós jelek, hőemelkedés, seb környéki hyperaemia jelentkezett, amely miatt antibiotikus terápia indult, amire a panaszok megszűntek. További egy esetnél szintén hyperaemia jelentkezett, illetve a sebből elhúzódóan haematoma ürült, amely antibiotikus terápiára, valamint rendszeres kötéscserékre az 5. posztoperatív napra megszúnt. Az ellátás során compartment syndromával nem találkoztunk. Posztoperatív transzfúzió adására egy eset kapcsán volt szükség.

A törés egy esetben panaszmentes 10 fok tengelyeltéréssel gyógyult. A gyógyulást követő funkció vizsgálatok során 2 esetnél tapasztaltunk hosszabb távon fennálló részben térd irányába is mutató lábszár panaszokat. Azok egy esetnél a fémkivétel utánra teljesen megszűntek, míg egy gyermeknél a terheléssel összefüggést mutató fájdalmak az implantátum eltávolítása után is fennmaradtak, majd a hosszú távon alkalmazott fizikoterápia hatásra enyhülést mutattak.

Az operált esetekből fémkivétel is történt, amelyet átlagosan $44 \pm 11$ héttel a primer mútétet követően végeztünk el. Fémkivételt követően egy esetnél tapasztaltunk elhúzódó sebgyógyulást, haematoma ürülést, lokális gyulladásos jeleket, amely miatt ismételt beavatkozás, a panaszos terület feltárása osztályos sebkezelés, antibiotikus terápia történt.

Az átlagos utánkövetés $68 \pm 31$ hónap volt, amely alatt végzett kontrollvizsgálatok során sem fizikálisan sem pedig radiológiailag nem igazolódott epiphyis sérülés, aszimmetrikus növekedés.
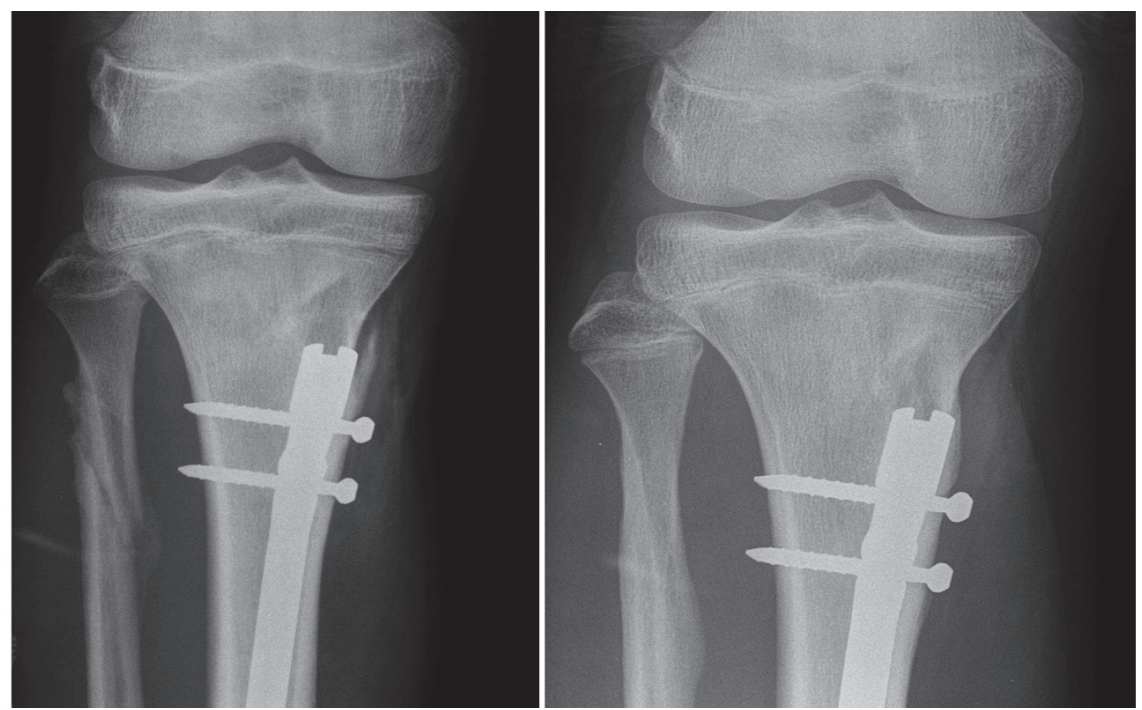

3. ábra Az ábra az egyik esetnél az implantátum behelyezésekor észlelt iatrogen corticalis sérülést mutatja, amely ellátást nem igényelt. 


\section{MEGBESZÉLÉS}

A gyermekkori tibia diaphysis törések kezelése az elmúlt időszakban jelentős változásokon ment keresztül. Az esetek többségénél - mint stabil törés, megfelelő törésállás - mindmáig a konzervatív terápia az elsőként választandó (5, $8,9)$, amelynek megfelelően kontrollált végig vitele sajnos hosszas immobilizációval jár. A sérültek mihamarabbi teljes funkciójú felépülési igényének növekedésével, valamint a mútéti technikák fejlődésével jelentős mértékben emelkedik az operatív beavatkozások száma. Míg a felnőtt lábszártörések esetén a mútétek aránya 90\%-hoz közelít (21), addig gyermekek kezelésénél Berruex és munkatársai által 1980ban publikált könyvükben 4,5\%-os operatív rátát említenek (3), amely saját 10 éves anyagunkban már $18,7 \%$-ot tesz ki.

A tibia diaphysist érintő törések többsége a test distalis harmadára lokalizáltak, amenynyiben a fibula nem érintett a végtagon, rövidülés nem áll be, de a konzervatív kezelés során varus irányú elmozdulás nagy eséllyel megjelenhet, így a mútéti ellátás indokolt, ugyanúgy, mint nem kielégítő primer törésállás, nyílt törések, ipsilateralis femurtörés, vagy épp lengő térd esetén $(8,22)$.

Az operatív ellátás során az ideális módszer egy olyan rögzítési technika alkalmazása lenne, amely egyszerúen, gyorsan és jól reprodukálhatóan biztosít stabil, terhelhető rögzítést, valamint jó funkcionális gyógyulást. Segítségével a végtagi funkció hamar visszanyerhető, továbbá a még aktív növekedési zónával rendelkezőknél arra károsító hatással nem rendelkezik, így későbbi növekedési elmaradást nem okoz. A flexibilis intramedullaris módszerek, illetve a külső rögzítési technikák az említett kritériumok közül számosnak megfelelnek, így előszeretettel alkalmazott eljárások $(1,2,5,7$, $8,10,11,14,18-21)$, azonban használatukkal nem minden esetben biztosítható kellő stabilitás és korai terhelhetőség. A serdülőkorban lévő gyermekek többsége már jobbára felnőtti testmértekkel, illetve fizikális aktivitással - az abba történő mielőbbi visszatérés igényével rendelkeznek, így a korábban említett mútétek kiegészítő rögzítést, vagy hosszas immobilizációt igényelnek.

Goodwin és munkatársai 19 esetet feldolgozó közleményükben, két serdülőkorban lévőnél a nagyméretű tibia miatt dupla (négyszeres) elasztikus intramedullaris szegezést alkalmaztak (7). Goodbody és munkatársai vizsgálatukban nagyobb méretű gyermek (50 kiló, illetve 14 év feletti csoport) tibiatörésnél végzett elasztikus szegezés mellett tapasztaltakat hasonlította fiatalabb és kisebb súlyúakéhoz. Eredményeikben nem észleltek különbséget a törésgyógyulással kapcsolatban, bár vizsgálatukban az operatív rögzítés mellé minden esetben kiegészítő külső rögzítést is alkalmaztak. Tapasztalataik szerint a flexibilis intramedullaris rögzítést kortól és súlytól függetlenül jó eredményekkel alkalmazható módszernek tartották (6). Ezzel ellentétben más szerzők, combcsonttörés esetén végzett vizsgálatuk során egyértelmúen több komplikációt és rosszabb eredményeket igazoltak flexibilis szegezésnél a kor és BMI növekedtével és distalisabb lokalizációban $(12,17)$.

A nagyobb fizikális méretekkel és a mielőbbi gyógyulás fokozott igényével rendelkező serdülőkorúak mútéti ellátása esetén a felnőtt lábszártöréseknél rutinként alkalmazott tömör velőúrszegezés jó alternatív eljárás lehet, de a növekedés lezárultát megelőzően az irodalom a nyitott epiphysis fuga sérülésének veszélye miatt általában nem javasolja. Nandra és munkatársai nyílt törésekkel foglalkozó tanulmányukban egy esetben említenek velőűrszeg használatot (14). Az irodalomban csupán egy közlemény foglalkozik ténylegesen a módszer gyermekeknél való alkalmazásával. Court-Brown és munkatársai 36 serdülőnél (13-16 éves) végzett felfúrásos üreges reteszelt velőurrszegezést. A mútét során a standard behatolási ponthoz közeli, de némiképp módosított módszert alkalmaztak, amellyel így is potenciális physis sérülést okoztak, azonban eredményeik szerint, az utánkövetés során a physis károsodása miatti növekedésben történő elmaradást nem tapasztaltak (4). Court-Brown és munkatársai által tapasztaltakkal ellentétben, a physist közvetlenül érintő beavatkozások végzésével kapcsolatban jelen közlemény szerzői is kifejezett óvatosságra intenek, így az a közlemény alapjául szolgáló eseteknél alkalmazott módszer alkalmával is elsődleges volt, ezért a mútétek során atípusos bevezetés használata történt. Az eljárás alatt a csont lefutására, illetve a szeg alakjára való tekintettel az implantátum bevezetés a megszokottnál nehezebb 
lehet, amely során fokozott a veszélye a csont corticalisán való sérülés okozásának (ahogy ezt 3 esetnél tapasztaltuk is), ezért nagyobb, 3-5 cm-es csontablak készítése szükséges.

A jelen közlemény eredményeiben tapasztalt átlagos törésgyógyulás $11,3 \pm 2,8$ hétnek mutatkozott, amely közel azonos Court-Brown és munkatársai által tapasztalt 11,5 héttel (4). Nandra és munkatársai eredményeiben az átlagos törésgyógyulás diaphysis töréseknél 13 hét volt, de tapasztalataik szerint a fixateur externe és a flexibilis rögzítés összehasonlítása során a külső rögzítő mellett lassúbb gyógyulás mutatkozott, bár felvetik, hogy ennek hátterében akár a sérülések komplexitása miatti különbségek is állhatnak (14). Kubiak és munkatársai elasztikus szegezésnél 7, fixateur externe-nél 18 hetet tapasztaltak (10), míg tisztán elasztikus szegezést alkalmazó közleményeknél a gyógyulást Vallamshetla és munkatársai 10 (19), Srivastava és munkatársai 20,7 hétnek találták (18).

A lábszártörések kiemelt jelentőségű szövődménye a compartment syndroma, amelynek előfordulása az irodalomban nagy szórást mutat. Jelen közlemény alapjául szolgáló 14 esetnél a szerzők compartment syndromát nem észleltek, amely hátterében feltételezhetően a kis esetszám áll. Ezzel ellentétben Goodbody és munkatársai az elváltozást vizsgálataikban 4,5\%-nak, Srivastava és munkatársai 8\%-nak, Court-Brown és munkatársai 8,3\%-nak tapasztalták $(4,6,18)$. McQueen és munkatársai 1388 lábszártörést szenvedett esetnél (átlagéletkor 39, megoszlás 12-98 év) végzett vizsgálatukban 11,5\%-ot tapasztaltak, továbbá nem találtak kapcsolatot a kis és nagy energiájú sérültek vagy nyílt és zárt törések között. Az előfordulás legerősebb kapcsolatát az életkorral igazolták, eredményeik korcsoportra történő bontásában a 12-19 korosztályban 222 esetből 20\%-nál igazolták az elváltozást (11).

$A$ vizsgálat eredményeiben észlelt minor szövődmények, felületes sebinfekció, sebgyógyulási zavar 3 esetnél (21\%) mutatkozott, amely némiképp magasabb más szerzők tapasztalataihoz viszonyítva. Az infekciós rátát flexibilis szegezés mellett Vallmashetla és munkatársai 5\%-nak, Srivastava és munkatársai $8 \%$-nak találták $(18,19)$, míg Nanadra és munkatársai nyílt törések esetnél 6,6\%-os felületes és 4,9\%-os mély infekciós rátát említettek (14).
Az észlelt különbségek hátterében inkább a kis esetszámot, mintsem a módszer nagyobb szövetkárosító lehetősége miatti fokozott fertőzési esélyt feltételezzük.

A jelen közleményben alkalmazott felfúrás nélküli, reteszelt, tömör velőűrszegezési módszer, hasonlóan az elasztikus technikákhoz, kis metszésből végezhető, jól reprodukálható beavatkozás, az intra- és perioperatív szövődmények azzal közel megegyeznek. A módszer kis fokú szövetroncsolással és alacsony infekciós rátával jár, továbbá a felfúrás hiánya az endostealis keringést sem károsítja. A módszer kiegészítő külső rögzítést nem igényel továbbá az intramedullaris elasztikus technikákkal ellentétben a posztoperatív részterhelés a mútét után korán megkezdhető, bár a felfúrásos szeggel szemben nem jelent azonnali teljes terhelés stabilitást (21).

A bemutatott gyermekkori tibia törések atípusos velőurrszegezéssel végzett ellátása során szerzett tapasztalatok alapján jelen közlemény szerzői, az implantátum gyártóval (Medimetal Kft., Eger, Magyarország) együttműködve, a módszer tökéletesítése érdekében elkészítették a velőúrszeg módosított (kifejezetten nyitott epiphysis melletti használatra szánt) változatát. A módosított rendszer TK junior tibia velőűrszeg néven 2017 év eleje óta érhető el intézetünkben.

\section{KÖVETKEZTETÉS}

A gyermekkori tibia diaphysis törések kezelésének elsődleges ellátási módja a konzervatív terápia, de a mútéti beavatkozások aránya egyértelműen növekszik. A külső rögzítők, illetve az elasztikus szegezési technikák jó eredményekkel alkalmazott eljárások, amelyek akár nagyobb testtömeg és testméret esetén is végezhetők. A jelen közleményben bemutatott eseteknél használt atípusos technikával végzett velőűrszegezési módszer, amely maximális epiphysis kíméletre törekszik, jó funkcionális alternatívakét alkalmazható bizonyos serdülőkori tibiatest törések mütéti ellátásakor. A módszer során tapasztalt korai terhelhetőség, a további külső rögzítés igényének hiánya és az alacsony szövődményráta szintén az eljárás alternatív beavatkozásként történő használata mellett szól. 


\section{Köszönetnyilvánítás}

A szerzők köszönik a Petz Aladár Megyei Oktató Kórház minden, jelen közlemény alapjául szolgáló sérült ellátásában közremúködő dolgozójának lelkiismeretes és áldozatos munkáját.

\section{IRODALOM}

1. Ács G., Hargitai E.: Gyermektraumatológia. Budapest. Medicina. 2001. 932 p.

2. Al-Sayyad M. J.: Taylor Spatial Frame in the treatment of pediatric and adolescent tibial shaft fractures. J. Pediatr. Orthop. 2006. 26. (2): 164-170. https://doi.org/10.1097/01.bpo.0000218522.05868.f9

3. Berruex P., Weber B. G., Brunner C. F., Freuler F.: Treatment of fractures in children and adolescents. Berlin. SpringerVerlag. 1980. 408 p.

4. Court-Brown C. M., Byrnes T., McLaughlin G.: Intramedullary nailing of tibial diaphyseal fractures in adolescents with open physes. Injury. 2003. 34. (10): 781-785. https://doi.org/10.1016/S0020-1383(03)00060-3

5. Fekete K., Ács G.: Traumatológia. Egyetemi tankönyv. Budapest. Medicina. 2016. 550 p.

6. Goodbody C. M., Lee R. J., Flynn J. M., Sankar W. N.: Titanium Elastic Nailing for Pediatric Tibia Fractures: Do Older, Heavier Kids Do Worse? J. Pediatr. Orthop. 2016. 36. (5): 472-477. https://doi.org/10.1097/BPO.0000000000000483

7. Goodwin R. C., Gaynor T., Mahar A., Oka R., Lalonde F. D.: Intramedullary flexible nail fixation of unstable pediatric tibial diaphyseal fractures. J. Pediatr. Orthop. 2005. 25. (5): 570-576. https://doi.org/10.1097/01.mph.0000165135.38120.ce

8. Gordon J. E., O'Donnell J. C.: Tibia fractures: what should be fixed? J. Pediatr. Orthop. 2012. 32. Suppl. 1: S 52-61.

9. Ho C. A.: Tibia shaft fractures in adolescents: How and when can they be managed successfully with cast treatment? J. Pediatr. Orthop. 2016. 36. Suppl. 1: S 15-18.

10. Kubiak E. N., Egol K. A., Scher D., Wasserman B., Feldman D., Koval K. J.: Operative treatment of tibial fractures in children: are elastic stable intramedullary nails an improvement over external fixation? J. Bone Joint Surg Am. 2005. 87. (8): 17611768. https://doi.org/10.2106/00004623-200508000-00014

11. McQueen M. M., Duckworth A. D., Aitken S. A., Sharma R. A., Court-Brown C. M.: Predictors of compartment syndrome after tibial fracture. J. Orthop. Trauma. 2015. 29. (10): 451-455. https://doi.org/10.1097/BOT.0000000000000347

12. Moroz L. A., Launay F., Kocher M. S., Newton P. O., Frick S. L., Sponseller P. D., Flynn J. M.: Titanium elastic nailing of fractures of the femur in children. Predictors of complications and poor outcome. J. Bone Joint Surg. Br. 2006. 88. (10): 1361-1366. https://doi.org/10.1302/0301-620X.88B10.17517

13. Muller M. E.: Manual of internal fixation: techniques recommended by the AO-ASIF Group. 3. ed. Berlin. Springer. 1991. https://doi.org/10.1007/978-3-662-02695-3

14. Nandra R. S., Wu F., Gaffey A., Bache C. E.: The management of open tibial fractures in children: a retrospective case series of eight years' experience of 61 cases at a paediatric specialist centre. Bone Joint J. 2017. 99. (4): $544-553$. https://doi.org/10.1302/0301-620X.99B4.37855

15. Rockwood C. A., Wilkins K. E., Beaty J. H., Kasser J. R.: Rockwood and Wilkins' fractures in children. 6th ed. Philadelphia. Lippincott Williams \& Wilkins. 2006. 1200 p.

16. Setter K. J., Palomino K. E.: Pediatric tibia fractures: current concepts. Curr. Opin. Pediatr. 2006. 18. (1): $30-35$.

17. Sink E. L., Faro F., Polousky J., Flynn K., Gralla J.: Decreased complications of pediatric femur fractures with a change in management. J. Pediatr. Orthop. 2010. 30. (7): 633-637. https://doi.org/10.1097/BPO.0b013e3181efb89d

18. Srivastava A. K., Mehlman C. T., Wall E. J., Do T. T.: Elastic stable intramedullary nailing of tibial shaft fractures in children. J. Pediatr. Orthop. 2008. 28. (2): 152-158. https://doi.org/10.1097/BPO.0b013e318165210d

19. Vallamshetla V. R., De Silva U., Bache C. E., Gibbons P. J.: Flexible intramedullary nails for unstable fractures of the tibia in children. An eight-year experience. J. Bone Joint Surg. Br. 2006. 88. (4): 536-540. https://doi.org/10.1302/0301-620X.88B4.17363

20. Vrsansky P., Bourdelat D., Al Faour A.: Flexible stable intramedullary pinning technique in the treatment of pediatric fractures. J. Pediatr. Orthop. 2000. 20. (1): 23-27. https://doi.org/10.1097/01241398-200001000-00006

21. Wiegand N.: Lábszártörés korszerü kezelésének értékelése klinikai és kísérletes vizsgálatokkal. Doktori (Ph.D.) értekezés. Pécs. 2009. $92 p$.

22. Yang J. P., Letts R. M.: Isolated fractures of the tibia with intact fibula in children: a review of 95 patients. J. Pediatr. Orthop. 1997. 17. (3): 347-351. https://doi.org/10.1097/01241398-199705000-00015

\section{Dr. Burkus Máté \\ burkusmate@gmail.com}

